\title{
HIPOTEKĀRĀ PARĀDNIEKA UN KREDITORA INTEREŠU NODROŠINĀŠANA MAKSĀTNESPĒJAS PROCESĀ
}

\author{
SECURING INTERESTS OF MORTGAGE DEBTOR \\ AND CREDITOR DURING INSOLVENCY PROCEDURE
}

\author{
Jānis Rozenfelds, Dr. iur. \\ Latvijas Universitātes Juridiskās fakultātes \\ Civiltiesisko zinātṇu katedras profesors
}

\section{Summary}

The main function of mortgage is to protect the secured creditor against all casualties, which could endanger the debtor's ability to perform his/her obligations towards the creditor. Hence, the capacity of mortgage to withstand the debtor's insolvency is one of the most crucial quality tests of any legal system. The current article explores whether Latvian legal system provides a mortgagee with adequate protection and comes to a conclusion that the situation is quite opposite. Insolvency law provides that if the creditor has not been vigilant enough and has missed deadline for declaring his/her claim to the insolvency administrator, then not only the creditor loses his/her right of claim, but the registration of mortgage in the Land Register may also be deleted.

Atslēgvārdi: hipotēka, saistība, zemesgrāmata, maksātnespēja

Keywords: mortgage, obligation, Land Register, insolvency

\section{Ievads}

Maksātnespējas process šajā rakstā aplūkots kā tiesiska rakstura pasākumu kopums, ${ }^{1}$ ko regulē Maksātnespējas likums (turpmāk - MNL). Atšķirībā no faktiskās maksātnespējas, kas var izveidoties arī attiecībā pret vienu kreditoru, maksātnespējas procesa raksturīga pazìme ir kreditoru kopums. Lìdztekus nepieciešamībai pēc iespējas nodrošināt saistību izpildi maksātnespējas procesam ir papildu funkcija - lïdzsvarot kreditoru intereses. ${ }^{2}$

Kreditoru kopuma interešu aizsardzības funkcija izpaužas kā pari passu (kreditoru līdztiesīgas grupēšanas) princips, kas savukārt tiek realizēts ar divu pakārtotu principu palìdzību - par condicio creditorum (līdztiesīgas attieksmes pret visiem kreditoriem) un pro rata (proporcionālas izmaksas) ${ }^{3}$ principu. Pirmais no tiem

1 Bērziņš G. Fiziskas personas maksātnespējas process. Rīga: TNA, 2018, 23. lpp.

2 The early history of bankruptcy law, p. 239. Pieejams: https://scholarship.law.upenn.edu/cgi/ viewcontent.cgi?article $=7663 \&$ context $=$ penn_law_review [aplūkots 27.02.2019.].

3 Black's Law Dictionary. 7th ed. Ed. in Chief B. A. Garner. West Group. St. Paul, Minn, 1999, p. 1236. 
ir pamatojums tiesībām atzīt par spēkā neesošiem atsevišķus iepriekš noslēgtus parādnieka darījumus, ja tie dod nepamatotas priekšrocības vieniem kreditoriem attiecībā pret citiem; otrs pamato vienlīdzīgu esošās parādnieka mantas sadali kreditoru starpā proporcionāli viṇu prasijumiem. Iepriekš minēto principu nepiel̦aujams pārkāpums ir tā sauktie sub rosa darījumi, proti, darījumi, kas vērsti uz parādnieka mantas pārdošanu slepenībā no kreditoru kopuma. ${ }^{4}$ Šì raksta mērḳis ir analizēt dažas atkāpes no iepriekš norādītajiem vispārīgajiem maksātnespējas procesa pamatprincipiem, kuras novērojamas Latvijā.

\section{Hipotekārā parādnieka interešu aizsardzība}

Maksātnespējas procesā parādnieka manta tiek pārdota saskaṇā ar Civilprocesa likuma (turpmāk - CPL) noteikumiem par mantas pārdošanu piespiestā izsolē (MNL 115. p. 1. d.).

CPL sākotnējā (vēsturiskajā) redakcijā izsoles sākumcenas noteikšanas pamatprincipi bija noteikti imperatīi. Izsoles sākumcena nedrīkstēja būt zemāka par to prasījumu summu, kuriem pēc piedzinēju prasījumu apmierināšanas secības ir priekšrocỉba salīdzinājumā ar visām uz nekustamo īpašumu vērstajām piedzin̄ām. Starplaiks starp izsoles izsludināšanu un izsoles norises dienu bija jo ilgāks, jo augstāka izsolāmā nekustamā īpašuma sākumcena.

Šādiem izsoles organizēšanas likumā paredzētiem pamatnoteikumiem bija svarīga nozīme, lai nodrošinātu, ka izsoles rezultātā tiek pieṇemta pēc iespējas augstāka cena.

CPL 607. ${ }^{1}$ pantā 2009. gadā izdarītās izmaiṇas šo kārtību atcēla. Spēkā esošā minētās normas redakcija paredz, ka izsole sākas no nekustamā īpašuma novērtējumā norādītās piespiedu pārdošanas vērtības, ko noteic sertificēts nekustamā īpašuma vērtētājs, nosakot nekustamā īpašuma piespiedu pārdošanas vērtību. Parādnieka tiesības lūgt nekustamā īpašuma atkārtotu novērtēšanu (CPL 604. p.) ir viņa vienīgā iespēja ietekmēt izsoles norisi.

Sūdzību, kas dod pamatu prasīt izsoles atzǐšanu par spēkā neesošu, ieinteresētās personas 10 dienu laikā no izsoles noslēguma dienas var iesniegt rajona (pilsētas) tiesas zemesgrāmatu nodaļā (CPL 617. p.).

Procesuālie līdzekḷi, ko paredz pašreizējā kārtība, var būt nepietiekami parādnieka interešu aizsardzībai. Paredzētā nekustamā īpašuma piespiedu izsoles kārtība gan varētu nodrošināt paātrinātu izsoles norises gaitu, tomēr tas var izrādīties nepietiekami efektīvs parādnieka aizsardzības līdzeklis.

Šaubas par pastāvošā mehānisma efektivitāti ieḳilātā nekustamā īpašuma īpašnieka interešu nodrošināšanā izraisa tas, ka pie šāda regulējuma ḳīlas kreditors būs ieinteresēts iegūt pēc iespējas augstāku cenu par izsolē pārdoto nekustamo ìpašumu, ja būs pilnīgi izslēgta interešu konflikta situācija.

Pastāvošā kārtība, kas paredz iespēju jebkuram no kreditoriem paturēt nekustamo īpašumu sev par nenotikušās izsoles sākumcenu (CPL 614.-615. p.), pilnībā šāda interešu konflikta iespējamību neizslēdz. Šì iemesla dēl, izsoles sākumcenai un izsoles norises ilgumam ir izšķiroša nozīme. Precīzi noteikta izsoles sākumcena un

4 Olivares-Caminal R. Creditor equality, secured transactions, and systemic risk: a complex trilemma. Law and Contemporary Problems, 2018, Vol. 81: 87, p. 88. Pieejams: http://datubazes.lanet.lv:3537/ ehost $/$ resultsadvanced? vid=20\&sid=8b21d7ae-a11c-4a1e-8cde [aplūkots 13.03.2019.]. 
pietiekami ilgs izsoles norises process ir svarīgi priekšnoteikumi ieḳīlātā nekustamā īpašuma īpašnieka interešu nodrošināšanai.

Parādnieka interešu aizsardzību neveicina arī izṇēmuma noteikums, ka tādā gadijumā, ja juridiskās personas maksātnespējas procesā parādnieka mantas pirmā izsole tiek atzìta par nenotikušu, otrā izsole rīkojama pēc pirmās izsoles noteikumiem ar lejupejošu soli (MNL 115. p. 2. d.).

Parādnieka interešu nodrošināšanai pastāv iespēja fiziskas personas maksātnespējas procesā noslēgt nodrošinātā kreditora un parādnieka vienošanos saglabāt mājokli, kas apgrūtināts ar ķīlu (MNL 146. p. 2. d.).

Šìs vienošanās mehānisms ir pietiekami sarežğìts, un tā saturs un izpilde pilnībā atkarīga no maksātnespējas administratora. ${ }^{5}$ Šìs parādnieka un hipotekārā kreditora separātās darbības, kuru atbilstību pārējo kreditoru interesēm izvērtē fiziskas personas maksātnespējas procesa administrators, ir Latvijas maksātnespējas procesa ìpatnība, kas neatbilst pari passsu principam, - tam piemìt sub rosa darījuma pazìmes.

Likums neparedz īpašus parādnieka interešu aizsardzības mehānismus. Tieši otrādi, parādnieka aizsardzība atbilstoši Maksātnespējas likumam ir vājāka salīdzinājumā ar Latvijas Civillikuma (turpmāk - CL) normām. Vispārīgo kịilas ņēmēja atbildību par rūpības trūkumu vai l̦aunprātību (CL 1328. p.) būtu problemātiski piemērot gadījumos, kad izsole notiek ar tiesas starpniecību.

Judikatūrā ir nostabilizējies secinājums, ka, pārdodot nekustamo īpašumu labprātīgā izsolē ar tiesas starpniecību, pārdodamā nekustamā īpašuma īpašnieka stāvoklis salīdzinājumā ar pārdošanu piespiedu izsolē ir nelabvēlīgāks, jo Civilprocesa likums, pretēji piespiedu pārdošanai, nekustamā ìpašuma labprātīgas izsoles sākumcenas noteikšanai kritērijus nav izvirzijis un neprasa tās pamatojumu. ${ }^{6}$ Piespiedu izsolē pārdodamā nekustamā īpašuma sākumcenas noteikšanas mehānisms līdz 2009. gada grozījumiem ${ }^{7}$ zināmā mērā garantēja, ka nekustamais ìpašums netiks novērtēts un pārdots par nesamērīgi zemu cenu.

Satversmes tiesā pausts viedoklis, ka piedzinēja atbildību par rūpības trūkumu vai l̦aunprātību iespējams piemērot arī tādā gadījumā, ja izsole norisinās ar tiesas starpniecību. ${ }^{8}$ Prasību pret administratoru par parādniekam nodarītajiem zaudējumiem var celt gada laikā pēc juridiskās personas maksātnespējas procesa vai fiziskās personas maksātnespējas procesa izbeigšanas (MNL 30. p.).

\section{Hipotekārā kreditora interešu aizsardzība}

Nodrošināto kreditoru prasījumi parasti apmierināmi vai nu separāti, tas ir, ārpus maksātnespējas vispārējā procesa (konkursa), kā to paredzēja Latvijas

5 Bērziņš G. 2018, 89. lpp.

6 SKC-1069/2018. Pieejams: http://at.gov.lv/lv/judikatura/judikaturas-nolemumu-arhivs/civillietudepartaments/hronologiska-seciba?year=2018 [aplūkots 23.11.2018.].

7 Saeimas likumprojekts 826/Lp9. Pieejams: https://titania.saeima.lv/LIVS/SaeimaLIVS.nsf/0/5733C9D 981AE5D55C22575160030605E?OpenDocument [aplūkots 11.01.2019.].

8 Satversmes tiesas spriedums lietā Nr. 2010-08-0. Pieejams: http://www.satv.tiesa.gov.lv/web/viewer. html?file=http://www.satv.tiesa.gov.lv/wp-content/uploads/2016/02/2010-08-01_Spriedums. pdf\#search $=$ [aplükots 13.03.2019.]. 
likums starpkaru periodā, ${ }^{9}$ Vācijas Maksātnespējas likuma 49. pants, ${ }^{10}$ vai arī pirms visu pārējo kreditoru prasījumu apmierināšanas (Lietuvas Uzṇēmumu bankrota likuma 34. pants ${ }^{11}$ ). Atšksirībā no Igaunijas Bankrota likuma, kas paredz nodrošināto prasījumu automātisku atzišanu, ${ }^{12}$ Latvijā arī šos prasījumus apstiprina administrators. Likumā nav norādīti kritēriji nodrošināto prasījumu atzīšanai vai noraidīšanai. Tā atkarīga no administratora lēmuma. Latvijas Maksātnespējas likums paredz apstākḷus, kuros administrators var hipotekārā kreditora pieteikto prasījumu neatzīt (MNL 75. p. 2. ${ }^{1}$ d.). Arī nodrošināto kreditoru interešu apmierināšanas kārtību noteic un kontrolē administrators (MNL 116. p.).

Administratora pienākumam elektroniski nosūtīt paziņojumu par maksātnespējas procesa pasludināšanu visiem zināmajiem parādnieka kreditoriem, kuru prasījuma tiesības ir nodrošinātas ar komercḳilu, zemesgrāmatā vai kug̣u reǵistrā registrētu hipotēku (MNL 141. p. 2. ${ }^{1}$ d.), ir formāls raksturs. Atšķirīibā no Igaunijas likuma ${ }^{13}$ administratoram nav ar likumu uzlikta pienākuma sazināties ar zemesgrāmatu nekavējoties pēc maksātnespējas procesa uzsākšanas. Šāda saziṇa ir neefektīva, jo tiesu praksē sastopami procesi par šādu viegli identificējamu nodrošināto prasījumu pirms termiṇa atzīšanu par spēkā neesošiem sakarā ar to, ka nodrošinātais kreditors nokavējis administratora noteikto pieteikšanās termiņu. ${ }^{14}$

Kreditoru prasījumi pret parādnieku iesniedzami administratoram mēneša laikā no dienas, kad maksātnespējas reǵistrā izdarīts ieraksts par parādnieka maksātnespējas procesa pasludināšanu (MNL 73. p. 1. d.).

Ja kreditors nokavējis šā panta pirmajā daḷā minēto prasījumu iesniegšanas termiṇu, viņš savu prasījumu pret parādnieku var iesniegt termiṇā, kas nav ilgāks par sešiem mēnešiem no dienas, kad maksātnespējas reǵistrā izdarīts ieraksts par parādnieka maksātnespējas procesa pasludināšanu, bet ne vēlāk kā līdz dienai, kad šajā likumā noteiktajā kārtībā sastādīts kreditoru prasījumu apmierināšanas plāns. Pēc šà termina iestājas noilgums, līdz ar to kreditors zaudē kreditora statusu un savas prasījuma tiesības pret parādnieku (MNL 73. p. 2. d.).

Tādējādi arī nodrošinātais kreditors maksātnespējas procesā var zaudēt savas prasījuma tiesības pat pirms šì prasījuma izpildes termiṇa iestāšanās. Par šì regulējuma juridisko pamatu, tāpat kā par tā pamatotību izteikti pretēji viedokḷi.

Kā juridiskais pamats šādai pirms termiņa saistības izbeigšanai norādīts tas, ka ir iestājies noilgums un ka likumā (MNL 73. p. 2. d.) norādìtais termiņš ir prekluzìvs termiņš. ${ }^{15}$ Minētajam termiṇam gan nepiemīt daudzas prasības noilgumam raksturīgās pazìmes.

${ }^{9}$ Civilprocesa nolikums. V pielikums (pielikums pie 1396. panta), 83. (22) panta 1) apakšpunkts. Citēts pēc: Latvijas konkursa likumi (Izṇemot Latgali) ar Senāta paskaidrojumiem un sastādītāja piezīmēm. Sast. R. Freymanns. Rīga: A. Gulbja izdevums, 1934, 98. lpp.

${ }^{10}$ Insolvency Statute of 5 October 1994 (Federal Law Gazette I page 2866), as last amended by Article 19 of the Act of 20 December 2011 (Federal Law Gazette I page 2854). Pieejams: https://www.gesetze-iminternet.de/englisch_inso/englisch_inso.html [aplūkots 27.02.2019.].

11 Lietuvas Uzñēmumu bankrota likums. Pieejams: http://www.lithuanialaw.com/lithuanian-enterprisebankruptcy-law-508 [aplūkots 14.03.2019.].

12 Bankruptcy Act, 103. §. Pieejams: https://www.riigiteataja.ee/en/eli/511072014018/consolide [aplūkots 27.02.2019.]

13 Ibid., 40. $\$$.

14 Sk., piemēram: SKC-1119/2016.

15 Bērziņš G. Atziņas par aktuālo tiesu praksi maksātnespējas jomā. Jurista Vārds, 05.04.2016., Nr. 14 (917), 10.-16. lpp. Pieejams: https://www.juristavards.lv/doc/268355-atzinas-par-aktualo-tiesu-praksimaksatnespejas-joma/ [aplūkots 28.02.2019.]. 
Civiltiesiskajās attiecībās jābūt noteiktībai - tāds ir arī vispārīgais prasības noilguma termiṇu pastāvēšanas pamatojums. ${ }^{16}$ "[..] noilguma institūts aizsargā parādnieku, tas ir noteikts parādnieka interesēs." 17 Termiņš kreditora pretenzijas "noilgumam” maksātnespējas procesā nepavisam neietekmē parādnieka stāvokli. Dzēšot hipotekāro prasījumu un pašu hipotēku, ieḳīātā nekustamā īpašuma vērtība neietekmēs ne bijušā hipotekārā kreditora, ne parādnieka mantisko stāvokli.

Noilguma, tāpat kā jebkura termiṇa, aprēḳināšanai svarīgs ir termiṇa tecējuma sākums, bet, “ja likumā nav noteikts cits noilguma tecējuma sākuma termiṇš [..], tad vadās no principa, ka noilgums sāk tecēt ar brīdi, kad kreditors uzzinājis vai viñam vajadzēja uzzināt par tiesību pārkāpumu". ${ }^{18}$

Ja par brīdi, kad kreditors uzzinājis vai viņam vajadzēja uzzināt par tiesību pārkāpumu, tiktu uzskatīta diena, kad maksātnespējas reǵistrā izdarīts ieraksts par parādnieka maksātnespējas procesa pasludināšanu, tad pret šādu pieṇēmumu cel̦ami šādi iebildumi:

1) likumā minētais brīdis ir nevis tas, kad kreditors uzzināja par pārkāpumu (viṇa konkrētajai saistībai termiņš, iespējams, vēl nebija iestājies), bet kad maksātnespējas procesa administrators publiski paziņoja par parādnieka maksātnespējas iestāšanos, tas ir, par jau kaut kad agrāk iestājušos pārkāpumu;

2) ar iepriekš minēto brīdi likums (MNL 73. p. 2. d.) saista nevis prasības noilguma tecējuma sākumu, bet gan termiņu, kādā likumā noteiktajā kārtībā sastādīts kreditoru prasījumu apmierināšanas plāns;

3) prasījumu iesniegšanas termiņšs, ja par tādu uzskatām laika posmu no briža, kad maksātnespējas procesa administrators publiski paziņoja par parādnieka maksātnespējas iestāšanos, līdz brīdim, kad sastādīts kreditoru prasījumu apmierināšanas plāns, pārtrauc citu prasības noilguma termiṇu, kāds būtu iestājies, ja kreditors vilcinātos iesniegt prasījumu sakarā ar parādnieka nokavējumu, kas nav saistīts ar parādnieka maksātnespējas iestāšanos.

Tādējādi minētais termiņš neatbilst prasības noilguma termiṇa jēdzienam pēc vairākām pazīmēm: tā tecējums nesākas ar pārkāpuma izdarī̌sanas brīdi, tas nav noteikts laika vienībās, un tā iestāšanās ir saistīta nevis ar likumā noteikta, bet gan noteiktas amatpersonas lēmumā paredzēta termiņa iestāšanos.

Izvērtējot, cik pamatota ir šāda termiņa pastāvēšana, jāpievēršas minētā termiṇa iestāšanās sekām, it sevišķ i - attiecībā uz tādiem kreditoru prasījumiem, kuri nodrošināti ar publisku hipotēku.

Atzīstot kreditora nepieteikto saistību par izbeigušos, tiesa uz attiecīgas maksātnespējas procesa administratora prasības pamata lemj par zemesgrāmatā ierakstītās hipotēkas dzēšanu, ${ }^{19}$ pamatojoties uz to, ka ķīlas pastāvēšana atkarīga no nodrošinātā prasījuma pastāvēšanas (CL 1283. p.), ko pieņemts dēvēt par ķīlas tiesības akcesoritātes principu. ${ }^{20}$

\footnotetext{
16 Torgāns K. Noilgums. Latvijas Republikas Civillikuma komentāri. Saistību tiesības (1401.-2400. p.). Sagatavojis autoru kolektīvs prof. K. Torgāna vispārīgā zinātniskā redakcijā. Rīga: TNA, 2000, 357. lpp.

17 Kārkliņš J. Noilgums piespiedu nomas attiecībās komerctiesībās. Jurista Vārds, 27.02.2018., Nr. 9 (1015), 14.-19. lpp.

18 Ibid., 360.-361. lpp.

19 Sk., piemēram: SKC-1119/2016.

20 Čakste K. Civiltiesības. Lekcijas. Raksti. Rīga: Zvaigzne ABC, 2011, 127. lpp.
} 
Kreditoru prasījumu nepieteikšanas seku regulējuma praktiskais iznākums ir tas, ka nepieteiktā hipotekāāā prasījuma vērtība, kas atbilstoši hipotēkas būtībai pieder nodrošinātajam kreditoram, pāriet konkursa masā. Šādam iznākumam nav nekāda pamatojuma. Par pamatotu atzīstams šāds secinājums: tiesas secinājums, ka prasijumu tiesību zaudēšana attiecas uz visiem iespējamiem kreditoriem, tostarp arī uz tādiem gadījumiem, kad parādnieks - fiziska persona - par kāda kreditora esamību ir noklusējis, nonāk pretrunā ar labticības principu un fiziskās personas maksātnespējas procesa mērkịi. ${ }^{21}$

Šāds praktiskais iznākums liecina, ka likumā nav pietiekami precīzi noregulēts administratora pienākums sazināties ar zemesgrāmatu un citiem publiskajiem registriem.

\section{Kopsavilkums}

1. Parādnieka intereses maksātnespējas procesā netiek pietiekami nodrošinātas. Likumā paredzētā kreditora atbildība par nolaidību vai l̦aunu nolūku, kas pielaists, pārdodot iek̦īlāto nekustamo īpašumu, nav piemērojama apstākḷos, kad izsoles rezultātus apstiprina tiesa. Lai pienācīgi nodrošinātu parādnieka intereses, nepieciešams precizēt noteikumus izsoles sākumcenas noteikšanai, paredzot, ka izsoles sākumcena nedrīkst būt zemāka par to prasījumu kopsummu, kas apmierināmi pirms tās personas prasijuma, kura lūgusi vērst piedziṇu uz nekustamo īpašumu.

2. Hipotekārā kreditora intereses maksātnespējas procesā netiek pietiekami nodrošinātas. Nepamatots ir Maksātnespējas likuma noteikums, ka ar hipotēku nodrošināti prasijumi, ja tie nav pieteikti šajā likumā noteiktajos termiņos, izbeidzas ar noilgumu. Ar hipotēku nodrošināto prasījumu apstiprināšanas kārtība izraisa nevajadzīgu administratīvo slodzi un var novest pie nenodrošināto kreditoru vai administratora netaisnas iedzīvošanās uz nodrošinātā kreditora rēķina.

${ }^{21}$ Bērziñš G. 2018, 75. lpp. 